\title{
New chitinozoan taxa from the lower Wenlock (Silurian) of the Welsh Borderlands, England
}

\author{
P. H. SWIRE \\ The Robertson Group plc, Llandudno, Gwynedd LL30 1SA, United Kingdom
}

\begin{abstract}
One new chitinozoan genus, Salopochitina, and three new chitinozoan species Salopochitina bella, Eisenackitina varireticulata and Eisenackitina spongiosa, all of early Wenlock age, are described from two British Geological Survey boreholes at Lower Hill Farm, Shropshire, and Eastnor Park, Hereford and Worcester. The new taxa have short stratigraphical ranges, are relatively abundant, and may be useful for correlation in successions from Wales and the Welsh Borderlands.
\end{abstract}

\section{INTRODUCTION}

Chitinozoans from the Wenlock of Wales and the Welsh Borderlands were first described by Eisenack $(1977,1978)$, who illustrated forms from the Much Wenlock Limestone Formation at Dudley in the West Midlands. From the Wenlock and Ludlow type areas, Dorning (1981) recorded the ranges of 35 chitinozoan taxa of stratigraphic value.

In 1973, the British Geological Survey (B.G.S.) drilled the Lower Hill Farm Borehole at (National Grid reference: SO $58179788), 1690 \mathrm{~m}$ at $092^{\circ}$ from Hughley church near Wenlock Edge, Shropshire (Text-fig. 1). This locality is on the outcropt of the upper part of the Coalbrookdale Formation, at $485 \mathrm{ft} \mathrm{OD}$ and about $1.3 \mathrm{~km}$ east south-east of the standard section for the base of the Wenlock series in Hughley Brook. The borehole was cored to $247.50 \mathrm{~m}$ in a sequence comprising part of the Coalbrookdale Formation, the Buildwas Formation, and part of the Purple Shales (Text-fig. 2). Detailed lithological and biostratigraphical data from this borehole, has been used to complement the generally poor surface exposures in the area, which include the international stratotype for the Wenlock Series (Bassett et al., 1975). In particular, graptolites recovered from the borehole were used to establish the presence of the Wenlock graptolite biozones (Bassett et al., 1975, pp. 5-8). In the only published micropalaeontological work on this borehole, Mabillard \& Aldridge $(1985$, p. 95$)$ recorded the amorphognathoides conodont Biozone of Walliser (1964) in the Purple Shales and the lower Buildwas Formation, the top of the zone was recognised at a depth of $239.14 \mathrm{~m}$ and the base at $242.21 \mathrm{~m}$.

The British Geological Survey Eastnor Park borehole (SO 74373809 ) was drilled in $1981,1500 \mathrm{~m}$ north east of Eastnor church at $130 \mathrm{~m}$ OD near Ledbury in Hereford and Worcester (Text-fig. 1). The borehole was cored to $103.90 \mathrm{~m}$ in a sequence comprising part of the Coalbrookdale Formation, the Woolhope Limstone and the Wych Beds (Text-fig. 2). There is no published account of this borehole. Mabillard (1981), in an unpublished thesis, documented the distribution of acritarchs, ostracods, conodonts and chitinozoa in a surface section (SO 7603 4685) at Birches Farm Lane, West Malvern, where a sequence parallel to part of that present in the Eastnor Park borehole, with Wych Beds overlain by the Woolhope Limestone Formation is seen; here the amorphognathoides conodont Biozone ranges from the upper Wych Beds into the lower Woolhope Limestone. The distribution of the conodonts and acritarchs (Mabillard, 1981) is consistent with the Llandovery/Wenlock boundary being placed above the base of the Woolhope Limestone Formation, at a level where calcareous sediments become more apparent in the section (Dr. R. J. Aldridge pers. comm.).

\section{SAMPLING AND PREPARATION TECHNIQUES}

Forty samples from the Buildwas and Coalbrookdale Formations of the Lower Hill Farm borehole, and eighteen from the Woolhope Limestone and Coalbrookdale Formation of the Eastnor Parkborehole were studied. Samples were taken at intervals of about $5 \mathrm{~m}$ in the Lower Hill Farm borehole; and at intervals of two metres in the Woolhope Limestone, and five metres in the Coalbrookdale Formation at Eastnor Park (Text-fig. 2). The samples are registered in the British Geological Survey's MPA series, (Lower Hill Farm borehole, MPA 26045 to 26084; Eastnor Park borehole, MPA 28410 to 28416 and 28474 to 28485 ). Slides and residues are held in the MPA collection of the Biostratigraphy Research Group, British Geological Survey, Keyworth. Figured specimens are registered in the MPK series of the Biostratigraphy Research Group at Keyworth (numbers MPK 5902 to 5918 ).

Standard palynological processing techniques were used with methods similar to those described by Neves \& Dale (1963) and Sarjeant (1974). Material was prepared for the scanning electron microscope by initially strew mounting residues on cover slips. The cover slips were then attached to small Cambridge stubs with high vacuum wax. Conducting paint was applied to improve electrical contact between the 


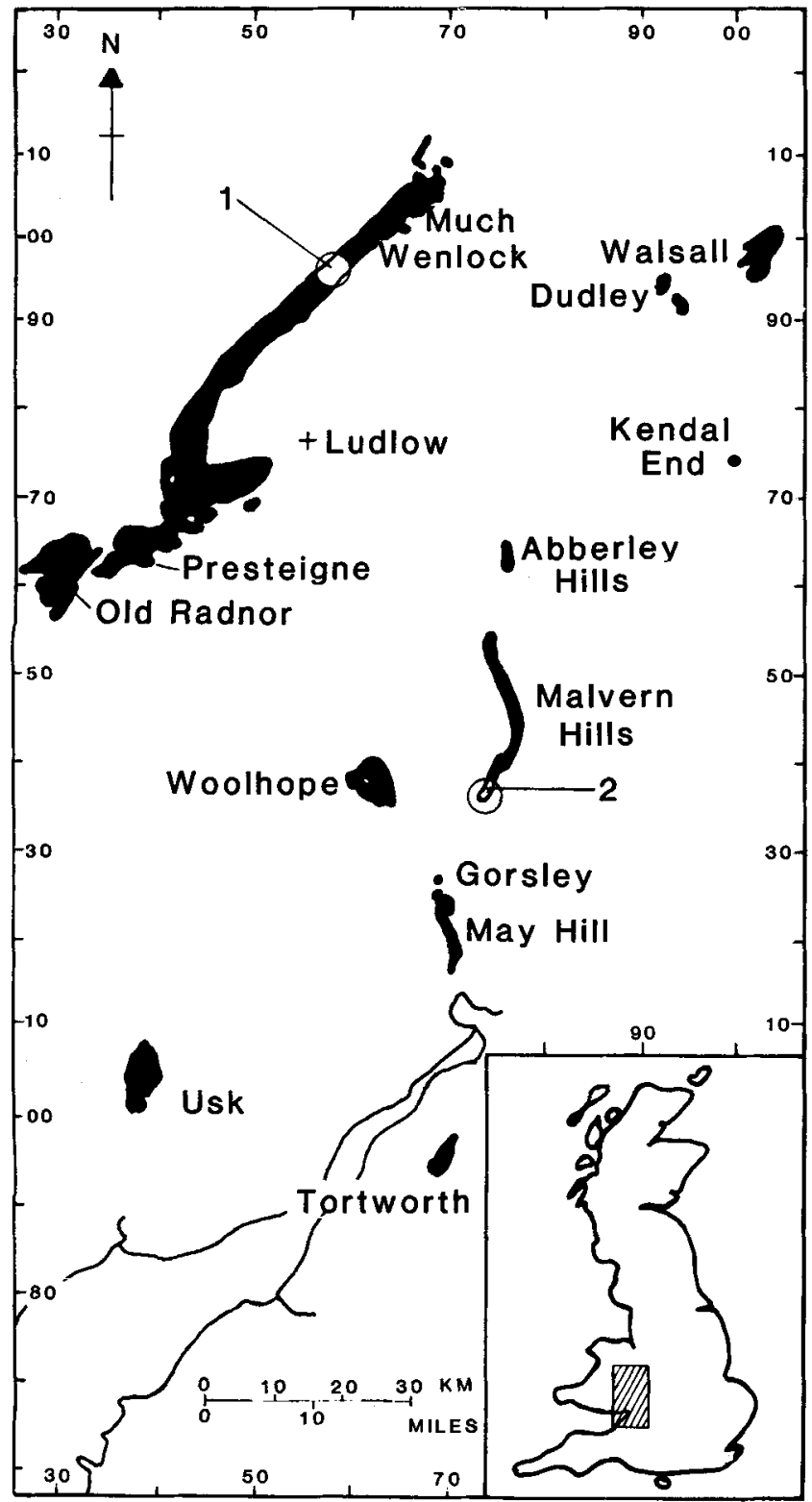

Fig. 1. Locality map for the two borehole sections, 1. B.G.S. Lower Hill Farm Borehole (SO 58179788), Shropshire and 2. B.G.S. Eastnor Park Borehole (SO 7437 3809), Hereford and Worcester; outcrop of Wenlock strata is shown in black.

cover slips and the stubs, prior to gold coating. The cover slips were logged by systematically traversing from top left to bottom right.

\section{RESULTS}

The organic residues recovered from the samples include both chitinozoans and acritarchs. The material studied is diverse, as is typical for open marine shelf sediments (Aldridge et al.. 1981), with the $\alpha$ diversity index (Fisher et al., 1943) for palynomorphs in the range 12.6 to 30.2 for the Lower Hill

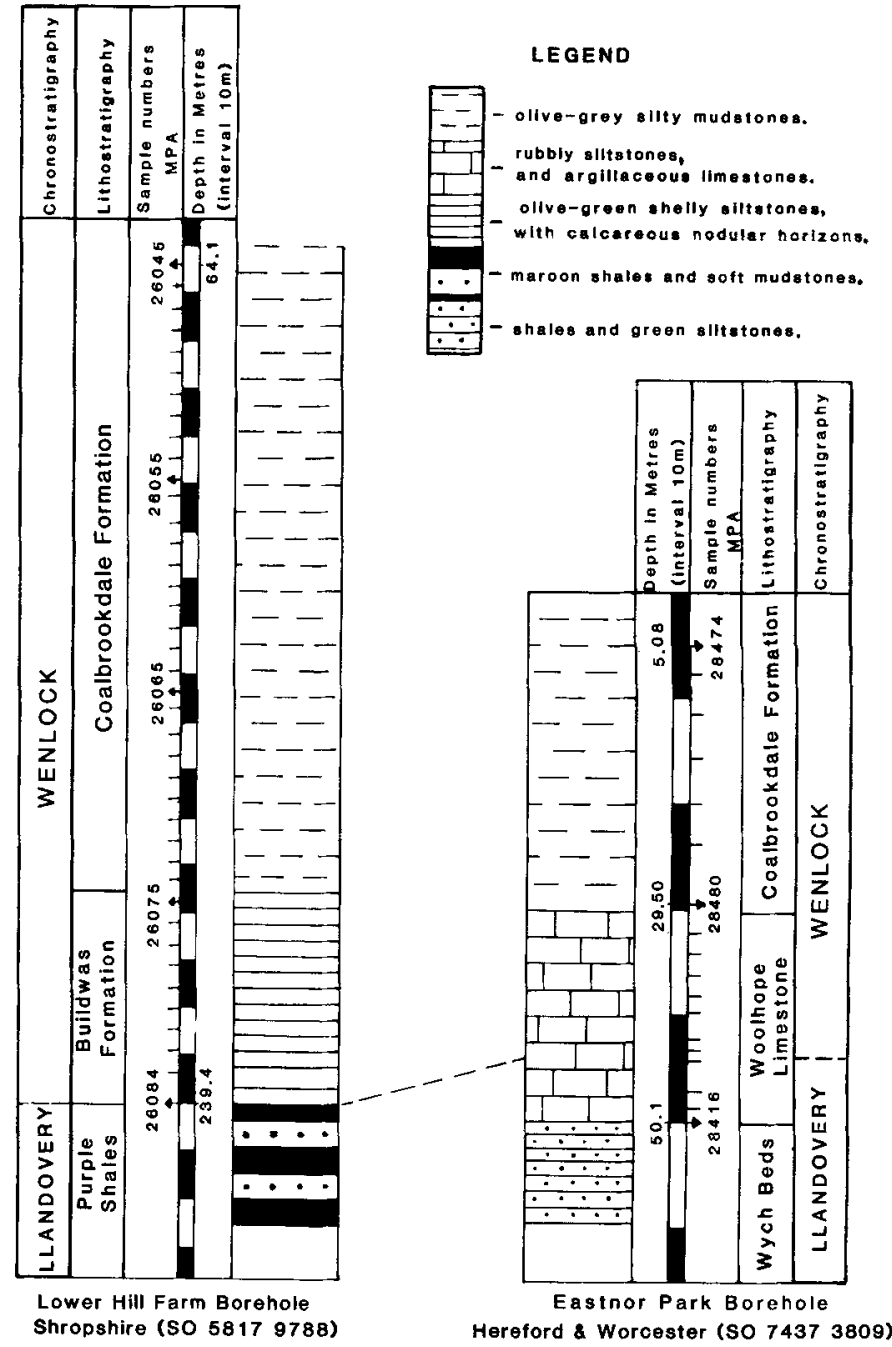

Fig. 2. Lithological sections.

Farm Borehole and 6 to 25.3 for the Eastnor Park Borehole. Absolute abundances determined, from the Lower Hill Farm borehole range from 6 to 136 chitinozoans /g and 500 to 2300 acritarchs /g, and in the Eastnor Park Borehole these range from 1 to 16 chitinozoans $/ g$ and 20 to 1000 acritarchs $/ g$.

The Lower Hill Farm Borehole residues include new chitinozoan taxa (Salopochitina bella gen. et sp. nov., Eisenackitina varireticulata sp. nov., and Eisenackitina spongiosa sp. nov.), from the Eastnor Park Borehole Salopochitina bella gen. et sp. nov. has also been recorded. Preservation of these chitinozoans is excellent, and detailed SEM and optical microscope work was carried out. The stratigraphical distribution of these new taxa is shown in Text-fig. 3. The apparently short ranges, (acritarch biozones W1 and W2 of Dorning \& Bell, 1987) and relatively high abundance (the new taxa account for up to $30 \%$ of a chitinozoan assemblage in a single sample) of the new chitinozoan taxa show that they are of biostratigraphical use, at least locally, in the lower Wenlock of Wales and the Welsh Borderlands. 


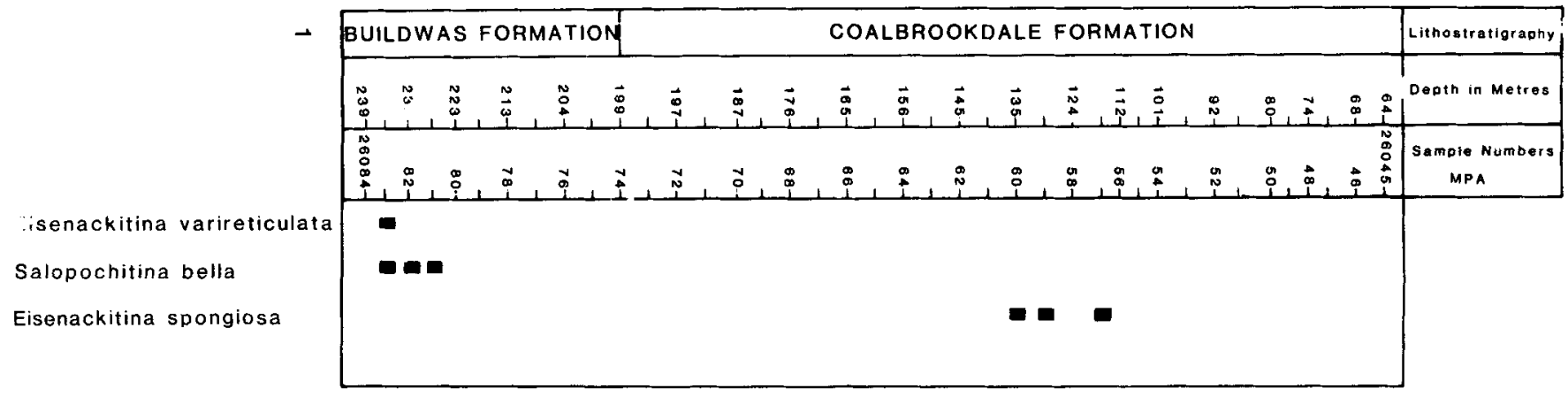

Salopochitina belia

$\mathbf{N}$

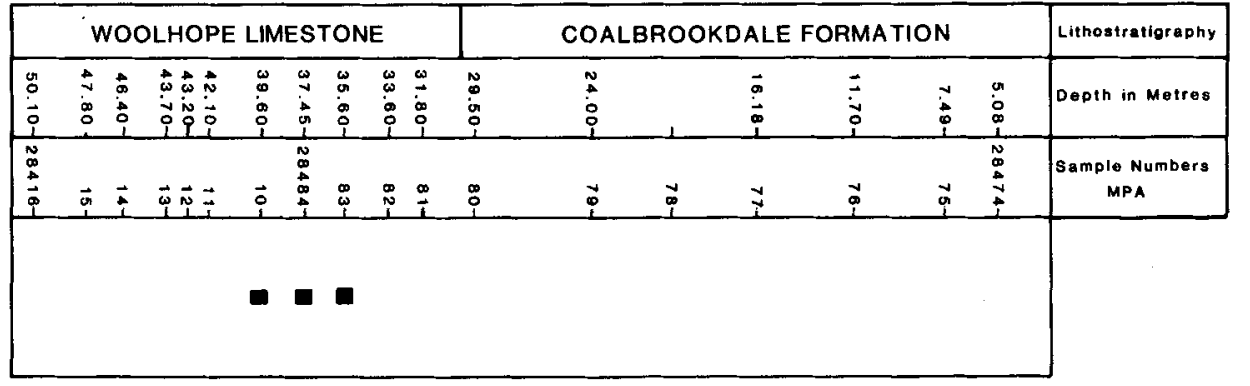

Fig. 3. Occurrence of the new chitinozoan taxa in the two borehole sections, 1. B.G.S. Lower Hill Farm Borehole, and 2. Eastnor Park Borehole.

\section{SYSTEMATIC DESCRIPTIONS Group Chitinozoa}

\section{Terminology}

Descriptive terminology used is that introduced by the commission internationale de microflore (Combaz et al., 1967), and later refined by Laufeld (1974, pp. 37-38).

\section{Genus Salopochitina gen. nov.}

Derivation of name. Salopia, Latin name for the area that is now called Shropshire.

Type species. Salopochitina bella gen. et sp. nov.

Diagnosis. Chitinozoans with little or no flexure and short neck. The aperture is widened and possesses a collar. The base is broadly rounded. Attached to the centre of the base, or to the basal margin, are one to three elongated appendices which are up to twice as long as the vesicle.

Remarks. The outline of the vesicle is superficially similar to that of Ancyrochitina Eisenack, 1955, but is shorter and more compact. The vesicle also possesses a collar, a feature that is not associated with species of Ancyrochitina. The basal margin of Ancyrochitina is provided with appendices which are short and sometimes branch. In Salopochitina the attachment of the appendices is either to the centre of the base, or to the basal margin, and the appendices are much longer and do not branch.

Plectochitina Cramer, 1964 differs from Salopochitina in having appendices that are distally connected, anastomosing and partly spongy; no connection of the appendices has been noted in Salopochitina and the appendices are solid for their entire length. Plectochitina also possesses a longer neck and deeper flexure than Salopochitina.

Salopochitina bella sp. nov. (Pl. 1, figs. 4, 5, 7; Pl. 2, figs. 1-3)

Derivation of name. Bella, Latin adjective for beautiful. Holotype. MPK 5913. Plate 2, fig. 3; MPA 26083, C2, P50/ 2. BGS Lower Hill Farm borehole, Shropshire (SO 5817 9788).

Occurrence. Sheinwoodian, Buildwas Formation, BGS Lower Hill Farm borehole, Shropshire; Sheinwoodian, Woolhope Limestone, BGS Eastnor Park borehole, Hereford and Worcester.

Diagnosis. The vesicle is subconical to ovoid with a broadly rounded base. The flexure, when present, is shallow and concave. The short neck widens orally and possesses a collar. There are one to three solid elongated appendices attached to the centre of the base or the basal margin of the vesicle; these appendices are up to twice as long as the vesicle and are widest where they join the base. The vesicle is unornamented. Dimensions. (in microns) length of vesicle 80-140 (holotype 130), maximum width of base 55-90 (holotype 72), width of aperture 30-53 (holotype 44), maximum length of appendix 30-250 (holotype 190). Specimens measured - 110 .

Description. The appendices are not branched, and apart from broadening proximally to their connection to the vesicle, are of equal width for their entire length, distal terminations 
of the appendices are generally blunt and rounded. When one appendix only is present, it is attached to the centre of the base; when two or three are present, they are attached to the basal margin of the vesicle. The appendices may possess a rugose ornament.

Remarks. The differing number of appendices can be accounted for by intraspecific variation; this is indicated by a morphotype (Pl. 2, fig. 1) that possesses one incipient appendix and two longer appendices. A similar stratigraphical occurrence for all the different types supports this idea.

The most similar species are Ancyrochitina longicornis and Ancyrochitina nodosa Taugourdeau \& De Jekhowsky, 1960. Ancyrochitina longicornis has one long appendix attached to the centre of the vesicle, and $A$. nodos $a$ has three which are attached to the basal margin. In both species the appendices are also of the same width for their entire length. The taxa differ from Salopochitina gen. nov. in the shape of the vesicle which in $S$. bella sp. nov. is subconical and in $A$. longicornis and $A$. nodosa is cylindro - spherical. Further difference between these forms is that in A. longicornis and $A$. nodosa the appendices are hollow, whereas in $S$. bella sp. nov. they are solid.

Genus Eisenackitina, Jansonius, 1964

Type species. Eisenackitina castor Jansonius, 1964.

Eisenackitina varireticulata sp. nov. (Pl. 1, figs. 1-3, 6; Pl. 2, figs. 4-7)

Derivation of name. From the Latin varietas and reticulatus, meaning variously reticulate.

Holotype. MPK 5902. Plate 1, fig. 1; MPA 26083, C4, P49/ 1. BGS Lower Hill Farm borehole, Shropshire (SO 5817 9788).

Occurrence. Sheinwoodian, Buildwas Formation, BGS Lower Hill Farm borehole, Shropshire.

Diagnosis. A wide subcylindrical to subconical chitinozoan with straight flanks, no neck and no flexure. The base is generally flat but may be slightly concave or convex, it possesses an angular margin. The vesicle has two wall layers, the inner whole, the outer forming a reticulate network which is joined to the inner by columns. The reticulate ornament is only present on the chamber, the oral tube being unornamented. Dimensions. (in microns) length of vesicle 85-135 (holotype 115), maximum width of base 66-145 (holotype 80), width of aperture 45-88 (holotype 55), maximum length of unornamented oral tube 27-52 (holotype 30). Specimens measured - 40 .

Description. In some specimens the ornament is damaged and is not clear; this effect could be preservational or may be due to damage during processing. The operculum when present, possesses a raised central 'boss'.

Remarks. The reticulate ornament of Eisenackitina varireticulata sp. nov. is similar to that of Acanthochitina barbata Eisenack, 1931; the latter differs, however in having a vesicle that is much longer and thinner, and an ornament that is entire.

This species is placed in the genus Eisenackitina, because of the subcylindrical vesicle shape, straight flanks, flat or convex base, and double walled vesicle. The presence of a reticulate ornament clearly distinguishes it from other species of Eisenackitina, with the exception of Eisenackitina spongiosa sp. nov. which in contrast possesses a reticulate ornament that covers the entire vesicle. The reticulum of $E$. Spongiosa sp. nov. is denser with the individual 'cells' of the reticulum being smaller in diameter than those of $E$. varireticulata sp. nov. due to a longer length of the supporting columns and therefore greater separation of the two wall layer. The reticulate ornament of $E$. varireticulata $\mathrm{sp}$. nov. is more visible in transmitted light than the orament of $E$. spongiosa sp. nov. No chains have been found.

Eisenackitina spongiosa sp. nov.

(Pl. 1, figs. 8-10; Pl. 2, fig. 8)

Derivation of name. From the Latin spongiosus meaning spongy or porous.

Holotype. MPK 5910. Plate 1, fig. 10; MPA 26057, C3, G33/ 2. BGS Lower Hill Farm borehole, Shropshire (SO 5817 9788).

Occurrence. Sheinwoodian, Coalbrookdale Formation, BGS Lower Hill Farm borehole, Shropshire.

Diagnosis. A wide subconical to subcylindrical chitinozoan. The flexure, when present, is shallow and concave. The base is flat to slightly convex and possesses an angular margin. The vesicle has two walls, an inner entire layer and an outer reticulate layer. The reticulate layer covers all of the vesicle and is joined to the inner wall by columns.

Dimensions. (in microns) length of vesicle 100-166(holotype 130 ), maximum width of base 87-133 (holotype 101), width of aperture 51-85 (holotype 55). Specimens measured - 30 .

\section{Explanation of Plate 1}

Specimens are curated in the MPK collection of the Biostratigraphy Research Group, British Geological Survey, Keyworth, Nottingham.

Figs. 1-3, 6. Eisenackitina varireticulata sp. nov.: fig. 1, MPK 5902, holotype, MPA 26083, C4, P49/1 (x 400); fig. 2, MPK 5903, oral view showing operculum with raised central 'boss', MPA 26083, C3, R41/2 (x 350); fig. 3, MPK 5904, MPA 26083, C6, R34/3 (x 350); fig. 6, MPK 5904, showing reticulate ornament, MPA 26083 C6, R34/3 (x 1100 ).

Figs. 4, 5, 7. Salopochitina bella gen. et sp. nov.: fig. 4, MPK 5905, MPA 26083, C3, T47/1 (x600); fig. 5, MPK 5906, MPA 26083, C6, B34/ 3 (x300); fig. 7, MPK 5907, illustrating attachment of appendix to basal margin, MPA 28410, C3, J44/3 (1100).

Figs. 8-10. Eisenackitina spongiosa n. sp: fig. 8, MPK 5908, shows dense reticulate ornament extending up to the aperture, MPA 26057, C5, H43/3 (x 1 100); fig. 9, MPK 5909, MPA 26057, C4, K40/4 (x 350); fig. 10, MPK 5910, holotype, MPA 26057, C3, G33/2 (x 400). 


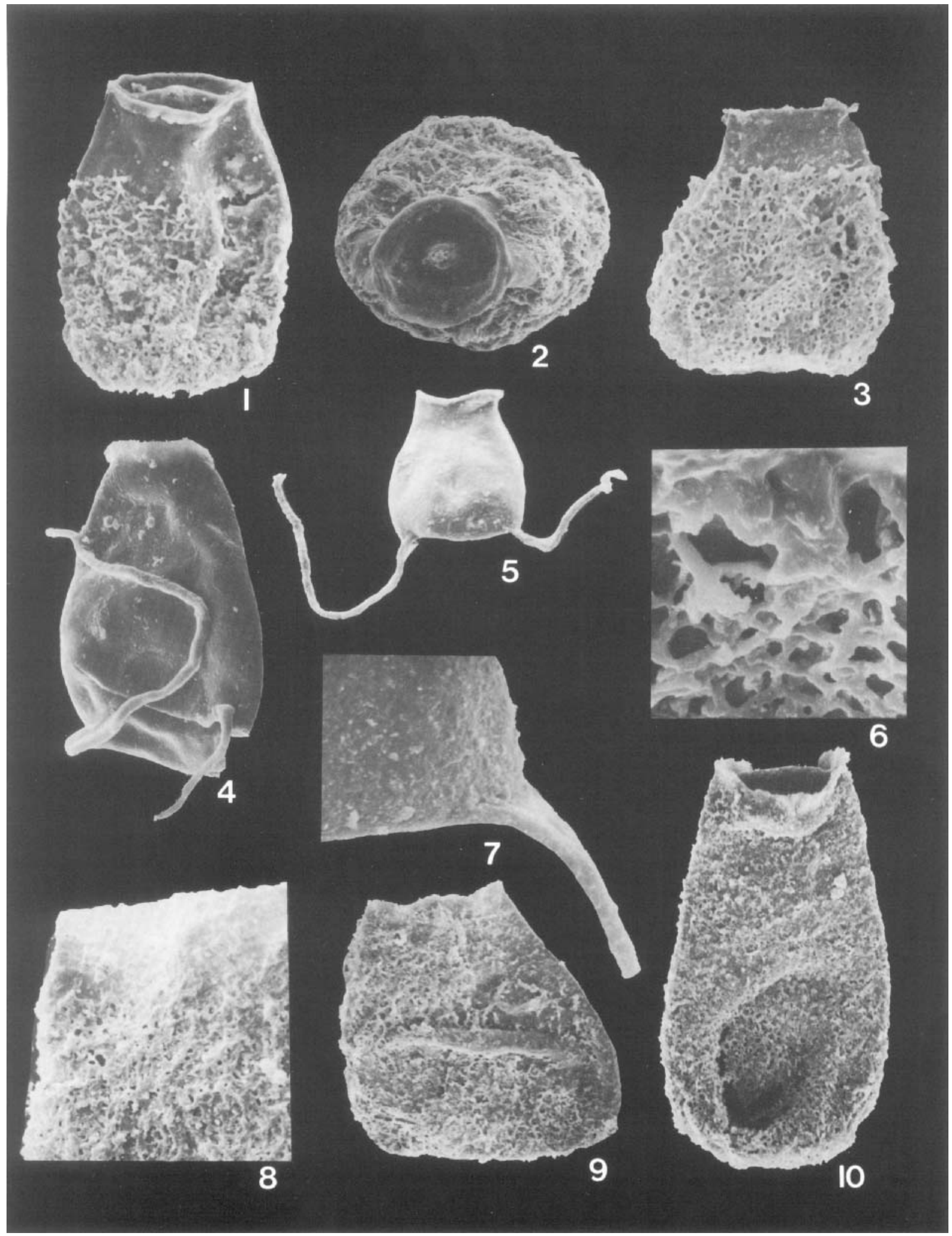


Description. Specimens possess a very dense reticulate ornament, which decreases in height orally. An operculum is sometimes present as a simple disc.

Remarks. The short subcylindrical vesicle distinguishes Eisenackitina spongiosa $\mathrm{sp}$. nov. from the much longer conical vesicle of Acanthochitina barbata Eisenack, 1931; also where as the reticulate ornament is entire on $E$. spongiosa sp. nov., on a single specimen of $A$. barbata there may be some spinose areas of ornament as well as a reticulate network. A. barbata also has a quite different stratigraphical range than $E$. spongiosa sp. nov. being widely reported from and restricted to the latest Caradoc and earliest Ashgill.

Eisenackitina spongiosa sp. nov. is placed in the genus Eisenackitina because of the subcylindrical vesicle shape, straight flanks, flat or convex base, and the two-layered vesicle wall. The entire reticulate ornament over the vesicle surface of Eisenackitina spongiosa sp. nov. is denser than in E. varireticulata sp. nov., and also distinguishes it from all other species of that genus. No chains have been found.

\section{ACKNOWLEDGEMENTS}

I acknowledge the financial support of a N.E.R.C. studentship, and the provision of samples by the British Geological Survey. Thanks are due to Dr. R. J. Aldridge and to Dr. S. G. Molyneux for advice in preparation of this paper; and I would also like to than Prof. C. Downie for his comments. Mrs. J. Wilkinson advised on cartography. Publication of information from B.G.S. records and samples has been approved by the Director, British Geological Survey (N.E.R.C.). All the work on this publication was undertaken at the Department of Geology, Nottingham University.

\section{Manuscript received May 1989}

Revised manuscript accepted February 1990

\section{REFERENCE}

Aldridge, R. J.. Dorning, K. J. \& Siveter, D. J. 1981 . Distribution of Microfossil Groups across the Wenlock Shelf of the Welsh Basin. In: Neale, J. W. and Brasier, M. D. (eds.). Microfossils From Recent and Fossil ShelfSeas, Ellis Horwood, Chichester, $18-30$.

Bassett, M. G., Cocks, L. R. M., Holland, C. H., Rickards, R. B. and Warren, P. T. 1975. The type Wenlock Series. Rep. Inst. Geol. Sci., no. 75/13, 19 pp.

Combaz, A., Calandra, F., Jansonius, J., Millepied, P., Poumot, C. \& Van Oyen, F. H. 1967. Microfossiles organiques du Paleozoique, 2, Les chitinozoaires, Morphographie. Centre Nation. Rech. Sci., $42 \mathrm{pp}$.
Cramer, F. H. 1964. Microplankton from three Palaeozoic Formations in the province of Leon (NW-Spain). Leidse Geol.Mededel., 30, 254-361. Leiden.

Dorning, K. J. 1981. Silurian chitinozoa from the type Wenlock and Ludlow of Shropshire, England. Rev. Palaeobotan. Palynol., 34, 205-208, Amsterdam.

Dorning, K. J. \& Bell, D. G. 1987. The Silurian carbonate shelf microflora: acritarch distribution in the Much Wenlock Limestone formation. In: Hart, M. B. (ed.). Micropalaeontology of Carbonate Environments, Ellis Horwood, Chichester, 266-287.

Eisenack, A. 1931. Neue Mikrofossilien des baltischen Silurs. $I$. Palaeont Z., 13, 74-118, Berlin.

Eisenack, A. 1955. Chitinozoen, Hystrichospharen und andere Mikrofossilien aus dem Beyrichia-Kalk. Senck.Leth.,36, 157-188. Frankfurt a. M.

Eisenack, A. 1977. Mikrofossilien in organischer Substanz aus den Middle Nodular Beds (Wenlock) von Dudley, England. $N . J b$. Geol. Palaont. Mh., 30, 25-35, Stuttgart.

Eisenack, A. 1978. Mikrofossilien in organischer Substanz aus dem Untoren Wenlock won Wrens Nest, Dudley, England. $N . J b$. Geol. Palaont, Mh., 21, 282-290, 1 Tab., Stuttgart.

Fisher, R. A., Corbet, A. S. \& Williams, C. B. 1943. The relation between the number of species and the number of individuals in a random sample of an animal population. Jour. Anim. Ecol., 12, $42-58$.

Jansonius, J. 1964. Morphology and classification of some chitinozoa. Bull. Canad. Petrol. Geol., 12, 901-918. Calgary.

Laufeld, S. 1974. Silurian Chitinozoa from Gotland. Fossils and Strata, 5, pp. 1-130.

Mabillard, J. E. 1981. Micropalaeontology and correlation of the Llandovery-Wenlock boundary beds in Wales and the Welsh Borderland. Unpublished Ph.D. Thesis, University of Nottingham.

Mabillard, J. E. \& Aldridge, R. J. 1985. Microfossil distribution across the base of the Wenlock series in the type area. Palaeontology, 28, 89-100, London.

Neves, R. \& Dale, B. 1963. A modified filtration system for palnological preparations. Nature, 198, 775-776. London.

Sarjeant, W. A. S. 1974. Fossil and living dinoflagellates, vii +182 pp. Academic Press, London and New York.

Taugourdeau, P. \& De Jekhowsky, P. 1960. Repartition et Description Des chitinozoaires Siluro-Devoniens de quelques sondages de la C.R.E.P.S., de la C.F.P.A. et de la S. N. REPAL au Sahara. Rev. inst. Franc. Petrole Ann. Combust. Liquides, 19, 845-871.

Walliser, O. H. 1964. Conodonten des silurs. Abh. Hess. Landesamt. Bodenforsch., 41, 106pp. Wiesbaden.

\section{Explanation of Plate 2}

Figs. 1-3. Salopochitina bella gen. et sp. nov.: fig. 1, MPK 5911, illustrates two long appendices and a third incipient one, MPA 26083, C2, T39/3 (x250); fig. 2, MPK 5912, the specimen possesses one long appendix which is attached to the centre of the base of the vesicle, the appendix is damaged and has developed a small split near to the attachment, MPA 26083, C1, V31/3 (x250); fig. 3, MPK 5913, holotype MPA 26083, C2, P50/2 (x250).

Figs. 4-7. Eisenackitina varireticulata sp. nov.: fig. 4, MPK 5914, MPA 26083, C1, W45/1 (x250); fig. 5, MPK 5915, MPA 26083, C2, H32/4 (x250); fig. 6, MPK 5916, MPA 26083, C1, U38/1 (x250); fig. 7, MPK 5917, MPA 26083, illustrates reticulate ornament, C2, P39/3 (x650).

Fig. 8. Eisenackitina spongiosa sp. nov.: MPK 5918, MPA 26057, C1, P47/2 (x250). 

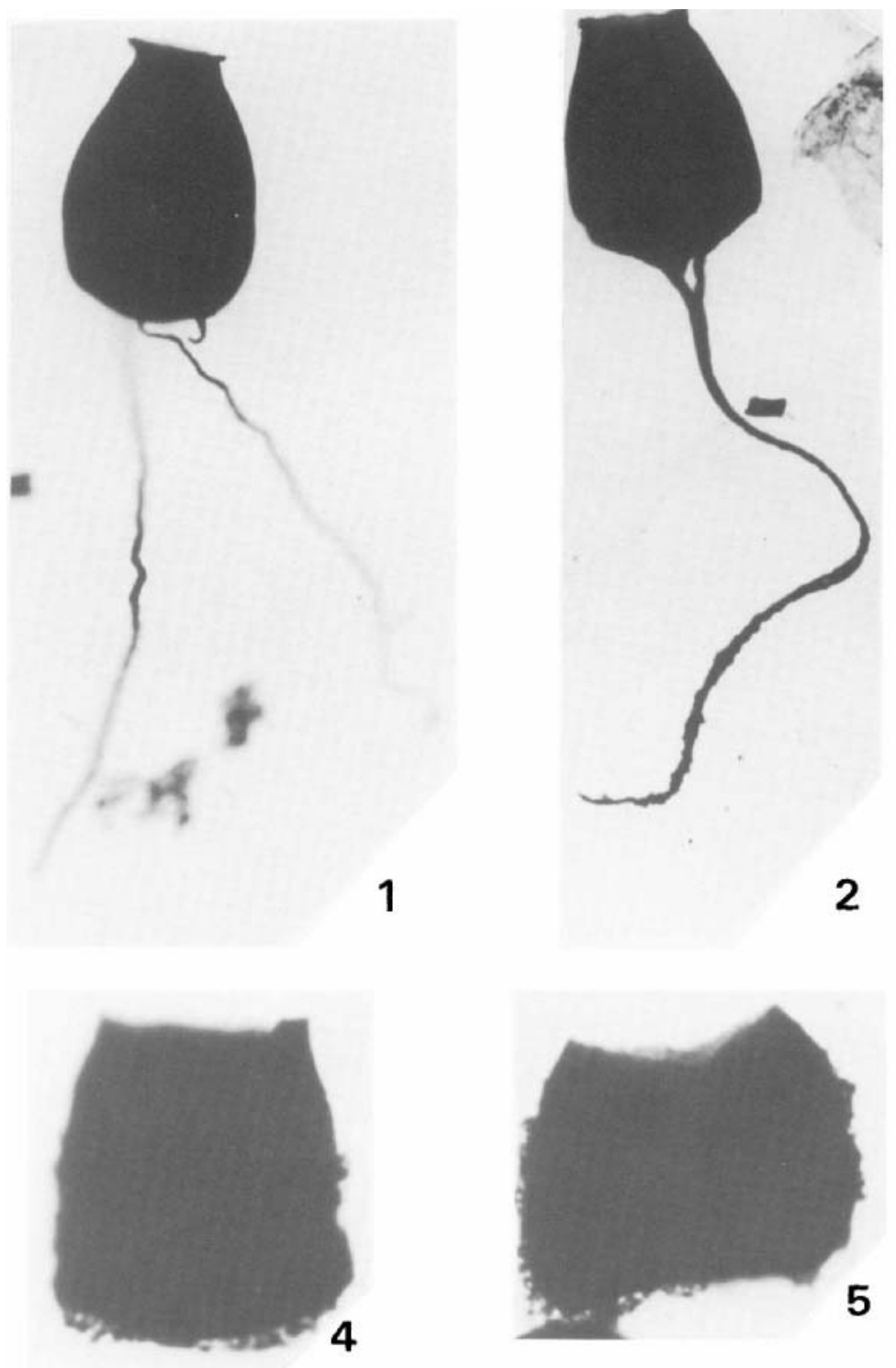

1

2
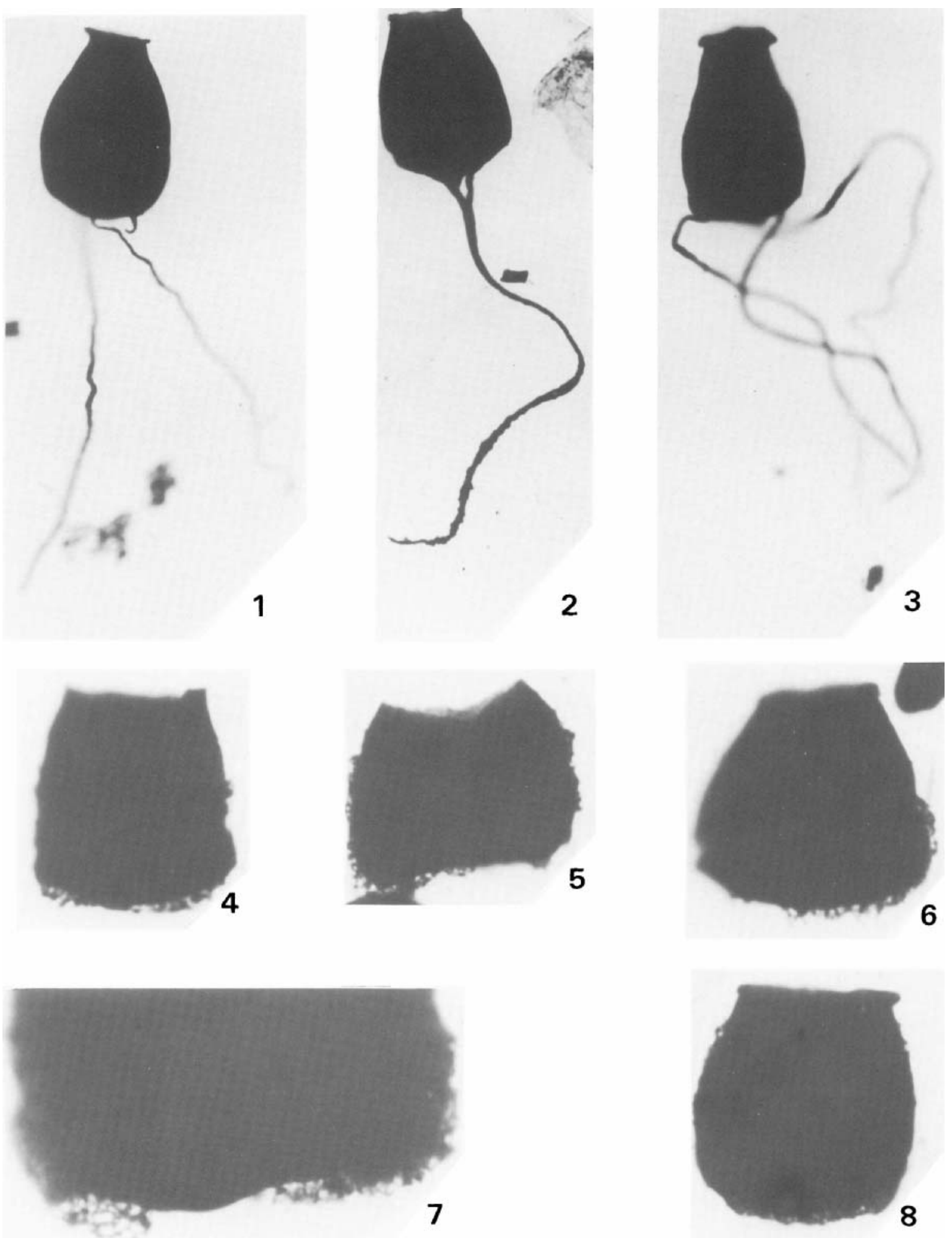